\title{
Sketsa Pelayanan Gereja Sebelum, Selama dan Sesudah Masa Pandemi COVID-19
}

\author{
Sketches of Church Ministry \\ Before, During, and After the COVID-19 Pandemic
}

\author{
Michael Teng, ${ }^{1}{ }^{*}$ Carmia Margaret ${ }^{2}$ \\ 1) Sekolah Tinggi Teologi SAAT, Malang \\ 2) Program Studi Magister Teologi Sekolah Tinggi Teologi SAAT, Malang \\ *Korespondensi: michael.teng@seabs.ac.id
}

\begin{abstract}
Abstrak: Masa pandemi COVID-19 dapat diibaratkan sebagai "cermin" yang menunjukkan keaslian atau realita wajah pelayanan gereja. Sebelum masa pandemi, telah ada observasi yang menunjukkan adanya keterpisahan antara teologi yang Alkitabiah dan praksis pelayanan kejemaatan serta adanya pengabaian terhadap hal-hal yang primer dalam pelayanan. Kedua observasi ini seolah-olah dibuktikan kebenarannya dalam masa pandemi. Melalui tiga penelitian tentang pelayanan gerejawi yang dilakukan di Indonesia selama masa pandemi, yaitu rangkaian penelitian dari Bilangan Research Center, Survei Nasional dan Rembuk Nasional dari Sekolah Tinggi Teologi SAAT, Malang, serta rangkaian penelitian dari Pusat Studi Pertumbuhan Gereja Sekolah Tinggi Teologi Amanat Agung, Jakarta, didapati bahwa gereja masih memiliki konsep teodisi yang tidak utuh atau proporsional, pelayanan gereja masih sangat bergantung kepada peran rohaniwan sebagai tenaga profesional dan terpusat secara sempit kepada aspek ibadah, ada kesenjangan yang serius antara generasi senior dan generasi muda, serta pelayanan gereja belum siap untuk berhadapan dengan teknologi. Merespons realita tersebut, artikel ini mengusulkan agar gereja melakukan penataan ulang pelayanan pascapandemi dalam enam hal, yaitu: membangun visi teologis yang bisa diejawantahkan dengan jelas dan utuh dalam pelayanan, menjadikan ibadah sebagai sentral tetapi bukan sebagai satu-satunya pelayanan yang penting, menggencarkan pembinaan dan pemuridan berbasis keluarga, memperkuat pelayanan pastoral yang menekankan relasi personal yang mendalam, memperhatikan pelayanan kepada generasi muda atau penerus, serta mengutamakan kapasitas pengutusan daripada kapasitas menampung orang di dalam gereja semata-mata.
\end{abstract}

Kata-kata kunci: Pandemi COVID-19, Gereja Pascapandemi, Penataan Ulang Pelayanan, Revitalisasi Gereja, Riset Gereja, Tantangan Pelayanan Gereja, Kenormalan Baru

\begin{abstract}
The COVID-19 pandemic can be likened to a "mirror" that shows the authenticity of church ministries' real face. Before the pandemic, there had been observations that showed a separation between biblical theology and the ministry's praxis and the neglect of the primary things in the ministry. These two observations seem to be proven to be true during the pandemic. In three studies on church services conducted in Indonesia during the pandemic, namely a series of researches from Bilangan Research Center, National Survey and National Dialogue from South East Asia Bible Seminary, Malang, as well as a series of researches from the Center for the Church Growth Studies of Amanat Agung Theological School, Jakarta, it was found that the church still has a disproportionate concept of theodicy. The church services are still very dependent on the clergy's role as professionals and narrowly centered merely on the worship ministry. There is also a serious gap between the older and the younger generation, and church services are not yet ready to deal with technology. Responding to this reality, the writers propose that the church needs to refocus its postpandemic ministry in six ways, namely: building a theological vision that can be embodied in the ministry, making worship ministry a central but not as a center in ministry, developing family-based discipleship, strengthening pastoral ministry that emphasizes deep personal relationships, paying attention to ministering the next generation, and prioritize the sending capacity rather than solely the seating capacity.
\end{abstract}




\section{PENDAHULUAN: PELAYANAN GEREJA DI ERA KENORMALAN BARU}

Pandemi COVID-19 yang melanda seluruh dunia termasuk Indonesia tidak diragukan lagi telah mempengaruhi dan mengubah segala lini kehidupan manusia termasuk dimensi pelayanan gereja. Setidaknya sejak 22 Maret 2020, sebagai respons atas anjuran presiden dan Surat Edaran Kementerian Kesehatan tertanggal 16 Maret 2020, hampir seluruh gereja di Indonesia menghentikan kegiatan ibadah dan pertemuan fisik yang dilakukan di lokasi tertentu, kemudian "memindahkannya" ke rumah masing-masing anggota. ${ }^{1}$ Sejak itu, seluruh aspek pelayanan gerejawi lainnya seperti "didesak" untuk berimprovisasi dan berubah bentuk, misalnya dari bentuk fisik menjadi bentuk digital. Tentu saja perubahanperubahan dinamika pelayanan dan "migrasi" ke dalam dunia digital ini merupakan sesuatu yang tidak mudah untuk dihadapi, apalagi jika

${ }^{1}$ Hasahatan Hutahaean, Bonnarty Steven Silalahi, Linda Zenita Simanjuntak, "Spiritualitas Pandemik: Tinjauan Fenomenologi Ibadah di Rumah," Evangelikal: Jurnal Teologi Injili dan Pembinaan Warga Jemaat 4, no.2 (Juli 2020): 234-249, https://doi.org/10.46445/ejti.v4i2.270. Hal ini tidak hanya terjadi di Indonesia tetapi juga di belahan dunia yang lain (lih. mis. Partners in Ministry, "How Did a Range of Churches Meet the Challenge of Church on Sunday $22^{\text {nd }}$ March 2020?," Partners in Ministry, Maret 2020, diakses 28 Agustus 2020, https://www.partners inministry.com/resources/churches-under-self-isolation).

${ }^{2}$ Ada dua penelitian terkait pelayanan gereja di tengah pandemi yang dilakukan oleh BRC. Penelitian yang pertama berjudul: "7 Tantangan Gereja di Masa Pandemi COVID-19 dan Alternatif Solusinya," dilakukan pada minggu ketiga April 2020 secara kualitatif dalam bentuk focus group discussion dengan melibatkan 6 pimpinan sinode dari berbagai aliran, jumlah dan sebaran gereja; serta 6 hamba Tuhan dari gereja mandiri. Hasil penelitian yang pertama ini telah diseminarkan secara daring (online) pada Rabu, 20 Mei 2020 oleh Handi Irawan. Kemudian, penelitian yang kedua berjudul: "Pelayanan dan Dinamika Gereja di Masa Pandemi COVID-19," dilakukan secara kuantitatif dengan menggunakan survei daring terhadap sekitar 560 responden laki-laki dan perempuan yang tercatat sebagai jemaat gereja arus utama, injili, dan Karismatik yang berada di perkotaan. Temuan dari penelitian ini telah diseminarkan pada 23-24 Juni 2020 dalam tema spesifik: "Realita Digitalisasi Pelayanan Gereja selama Pandemi COVID-19" oleh Handi Irawan dan "Keterlibatan Sosial dan Kondisi Keuangan Gereja" oleh Bambang Budijanto dan Kresnayana Yahya. Sebagai mengingat belum adanya kejelasan tentang akhir dari pandemi mematikan ini.

Dengan banyak dan mendadaknya desakandesakan perubahan yang terjadi, gereja-gereja, lembaga Kristen, bahkan sekolah teologi di Indonesia turut memberikan berbagai respons, misalnya melalui proyek penelitian, seminar, lokakarya, atau gerakan pelayanan. Ada setidaknya tiga proyek atau penelitian yang cukup signifikan diminati dan berkontribusi bagi gereja-gereja, khususnya dalam aras injili. Pertama, rangkaian penelitian dari Bilangan Research Center (BRC) yang dimulai sejak minggu ketiga April 2020. ${ }^{2}$ Kedua, Survei Nasional tentang pelayanan gereja di masa pandemi dan Rembuk Nasional (Rembuknas) dari Sekolah Tinggi Teologi SAAT, Malang, pada awal Mei 2020. ${ }^{3}$ Ketiga, rangkaian survei dari Pusat Studi Pertumbuhan Gereja (PSPG) Sekolah Tinggi Teologi

tambahan, diadakan pula pendalaman dari hasil survei ini dalam bentuk studi kasus pada 30 Juni dan 1 Juli 2020, bertajuk: "Membangun Digital Capability Gereja" dan "Integrasi Ibadah O2O untuk Meningkatkan Spiritualitas Jemaat," oleh para pimpinan gereja yang mewakili aliran arus utama, injili, dan Karismatik.

${ }^{3}$ Survei Nasional dilakukan oleh Tim Lembaga Penelitian dan Pengabdian Masyarakat (LP2M) STT SAAT bekerjasama dengan Persekutuan Alumni STT SAAT pada 19-28 April 2020 melalui penyebaran kuesioner daring. Kuesioner diisi oleh 651 responden dengan 628 data yang dapat dianalisa. Responden terdiri dari lulusan STT dan penatua/majelis/pengurus jemaat yang berasal dari sekitar 400 gereja. Hasil penelitian dibaca oleh Michael Teng, Sylvia Soeherman, dan Junianawaty Suhendra, dan disampaikan pada Rembuk Nasional pada 11-18 Mei 2020. Selain presentasi hasil survei, dalam Rembuknas ini juga dilakukan: (1) Pendalaman hasil survei yang diisi oleh beberapa pembicara kunci dari gereja perkotaan, gereja pedesaan, gereja berbasis anak muda atau digital, bidang pendidikan, bidang psikologi, dan bidang sosio-ekonomi; serta (2) Perencanaan strategis dan upaya tindak lanjut dalam bentuk project groups yaitu 18 kelompok bidang pelayanan yang berbeda. Beberapa dari project groups ini kemudian membuat komunitas atau wadah kolaborasi untuk memikirkan revitalisasi pelayanan di bidangnya, seperti: KOMPAK (pemuridan keluarga); BERLIAN (pelayanan Lansia); Youth Collaboration (pelayanan kaum muda); KOPING (konseling dan Halo Konselor); Komunitas Pendidik Kristen +62 ; pelayanan digital, dan sebagainya. 
Amanat Agung, Jakarta, pada akhir Mei dan Juli $2020 .^{4}$

Tiga proyek penelitian ini (tanpa mengabaikan penelitian-penelitian lainnya) tampak bersama-sama menggumulkan pertanyaan-pertanyaan seperti: apa, dan seberapa jauh, pengaruh pandemi COVID-19 bagi dinamika pelayanan gereja? Apa dan bagaimana keadaan riil dari gereja (dan jemaat) dalam masa pandemi COVID-19? Apa yang bisa direfleksikan gereja melalui realitas ini, khususnya berkaitan dengan "hasil" pelayanannya selama ini? Dan, tentu saja, bagaimana gereja harus menjalankan berbagai bidang pelayanan selama dan setelah masa pandemi?

Artikel singkat ini ditulis untuk menunjukkan sebuah sketsa tentang pelayanan gereja sebelum dan selama masa pandemi berdasarkan kumpulan hasil laporan penelitian yang telah diadakan. Kenyataan riil pelayanan gereja selama masa pandemi sedikit banyak (meskipun tidak sepenuhnya) dapat membukakan wajah pelayanan gereja sebelumnya dan sesungguhnya. Dengan kata lain, masa pandemi ini menjadi momen yang tepat bagi para praktisi pelayanan gereja untuk bercermin tentang keadaan pelayanannya selama ini. Tidak berhenti sampai di situ, data-data yang diperoleh dari penelitian selama masa pandemi juga dapat menjadi semacam acuan untuk memikirkan prinsip, strategi, bahkan arah pelayanan yang harus dikembangkan di dalam masa kenormalan baru atau bahkan setelah masa pandemi, jika tetap ingin terus berkiprah bahkan menjadi semakin efektif di tengah dunia yang berubah.

${ }^{4}$ STT Amanat Agung juga menyelenggarakan dua survei, yaitu: "Pengalaman Ibadah Jemaat dalam Ibadah Online" dan "Spiritualitas Kaum Muda di Masa Pandemi COVID-19." Keduanya dilakukan dengan cara kuantitatif melalui survei daring. Survei yang pertama dilakukan pada 22-29 Mei 2020 dengan 719 responden dari 169 gereja lokal dari 56 sinode dan hasilnya dipresentasikan pada 8 Juni 2020. Survei yang kedua dilakukan pada 19-26 Juni 2020 dengan diikuti oleh 1005 responden berusia 15-24 tahun yang berafiliasi pada gereja tertentu dari 87 kabupaten/kota atau 28 provinsi di Indonesia dan hasilnya dipresentasikan pada 8 Juli 2020.

\section{PELAYANAN GEREJA SEBELUM MASA PANDEMI: SEBUAH OBSERVASI}

Ketertarikan untuk menyelidiki realitas pelayanan gereja tentu saja telah muncul sebelum masa pandemi, dan bahkan jika tidak ada pandemi sekali pun. Sudah begitu banyak buku, penelitian, dan berbagai upaya lain yang dilakukan untuk mencari tahu "mengapa," "ada apa," serta "mau di bawa ke mana" pelayanan gereja di tengah kompleksitas zaman. Tentu saja pertanyaan dan keprihatinan ini juga tidak muncul dari ruang vakum. Ada beberapa observasi yang diperoleh dari berbagai literatur, pengalaman, dan riset-riset sebelumnya dari berbagai belahan dunia dan ragam bentuk pelayanan.

Pertama, ada observasi bahwa telah terjadi keterpisahan antara teologi yang alkitabiah tentang gereja dan praksis pelayanan jemaat. Tampaknya ada pedang tajam yang membelah prinsip-prinsip teologi yang didapat dari Kitab Suci, buku-buku, serta ruang kelas teologi, dengan realita praksis pelayanan di tengahtengah jemaat. ${ }^{5}$ Adalah jamak bagi para "teolog" untuk mendulang kekayaan pemikiran teologi Kristen tetapi hidup terpisah dan tidak relevan sama sekali dengan kompleksitas pergumulan hidup umat, pun di saat yang bersamaan para praktisi pelayanan gerejawi berpikir bahwa kebenaran-kebenaran biblikal dan teologis yang telah ditemukan tidak relevan atau tidak operatif dalam keunikan konteks pelayanannya. Keterpisahan ini sedikit banyak menjelaskan mengapa pelayanan gereja terasa stagnan bahkan "mandul" di tengah begitu banyak buku, seminar, karya,

${ }^{5}$ Ed Stetzer, "Why Being Fruitful is as Important as Being Faithful," Vision Room, diakses pada 27 Desember 2020, https://www.visionroom.com/fruitful-important-faith ful; Craig Hamilton, Wisdom in Leadership: The How and Why of Leading the People You Serve (Sydney: Matthias Media, 2015), 11-12; Timothy Keller, Center Church: Doing Balanced, Gospel-Centered Ministry in Your City (Grand Rapids: Zondervan, 2012), 12-15. Keller bahkan membuat daftar panjang buku-buku yang berisi "teologi" tentang gereja yang alkitabiah, serta buku-buku yang berisi "tips praktis" menjalankan gereja yang berhasil. 
penelitian, dan pemikiran yang tentu dapat memberikan berbagai sumbangsih yang berharga.

Kedua, ada pula observasi bahwa gereja telah mengabaikan, entah disadari atau tidak, halhal yang esensial dalam pelayanan, dan menggantikan fokusnya kepada hal-hal yang tidak primer. Pengabaian ini terlihat misalnya dari ambiguitas tolok ukur atas "kesuksesan" gereja. Banyak gereja yang berpikir bahwa kesuksesan dalam pelayanan berarti peningkatan jumlah kehadiran, keuangan, dan ekspansi pelayanan secara fisik, padahal Kitab Suci jelas mengatakan bahwa kesuksesan utamanya berbicara mengenai penjangkauan, pertobatan dan pertumbuhan jiwa-jiwa di dalam Kristus, sebagai bentuk ketaatan seluruh umat Tuhan pada Amanat Agung Tuhan Yesus. ${ }^{6}$ Secara praktis, pengabaian ini juga dapat terlihat melalui pergeseran fokus pelayanan: dari pelayanan jiwa-jiwa kepada orientasi program-program, dari pertumbuhan rohani kepada penekanan pada metodemetode, dari kerohanian yang sejati kepada kesibukan dengan berbagai kegiatan, dari fokus pelayanan firman kepada keahlian manajerial organisasi semata, dan akhirnya, pergeseran "hasil," dari murid Kristus yang setia kepada para penggemar kekristenan atau tokoh-tokoh Kristen tertentu belaka. ${ }^{7}$

Jika berbagai observasi ini diringkaskan dengan satu kata, maka "krisis" yang melanda pelayanan gereja, bahkan sebelum masa pandemi, adalah: ambiguitas. Adanya ambiguitas dalam refleksi dan visi teologis terhadap gereja dan pelayanannya, ambiguitas tolok ukur keberhasilan, ambiguitas tujuan dan sasaran yang hendak dicapai, bahkan juga ambiguitas cara dan metodologi yang digunakan. Persoalannya, ambiguitas ini telah berlangsung secara masif, luas, dan sirkular seperti "lingkaran setan," dari satu penyebab kepada satu akibat

\footnotetext{
${ }^{6}$ Keller, Center Church, 11-12.

${ }^{7}$ Bdk. Collin Marshall dan Tony Payne, The Trellis and the Vine: The Ministry Mind-shift that Changes Everything (Sydney: Matthias Media, 2009), 7-15; Edmund Chan, $A$
}

yang menghantar pada penyebab baru dan akibat baru, dan begitu seterusnya. Agaknya dibutuhkan semacam "interupsi Ilahi” untuk bisa menyadarkan gereja dari ambiguitas ini dan menghantarkannya pada haluan yang semestinya. Untuk itu, para pemimpin gereja perlu bersedia untuk memikirkan ulang halhal yang primer dan esensial dalam kehidupan berjemaat, serta mengalibrasi segala praksis pelayanan gerejawi yang dilakukan selama ini agar selaras dan mendukung hal-hal esensial tersebut.

\section{PELAYANAN GEREJA SELAMA MASA PANDEMI: SEBUAH REFLEKSI}

Apakah lantas masa pandemi ini dapat menjadi "interupsi Ilahi" yang dibutuhkan tersebut? Melihat berbagai fenomena pelayanan gereja selama ini dan temuan-temuan dari berbagai riset, dalam skala tertentu, pandemi ini dapat dipandang sebagai semacam "interupsi Ilahi" yang membangunkan gereja dari ambiguitas panjangnya. Penghentian "paksa" dan tiba-tiba dari berbagai kegiatan dan bentuk pelayanan, mau tidak mau, membuat para praktisi pelayanan gereja berhenti sejenak dari rutinitas dan melihat ulang apa yang telah dikerjakan, atau apa yang telah terjadi, selama ini. Jika "interupsi Ilahi" pandemi ini direspons dengan tepat oleh gereja-gereja, maka akan muncul pembaharuan yang hakiki dalam kehidupan berjemaat. Ada beberapa isu dalam konteks riil pelayanan gereja yang tercermin dalam berbagai temuan penelitian, yang perlu dipikirkan ulang dan direspons secara tepat oleh para pemimpin gereja.

Pertama, masa pandemi menunjukkan masih minimnya konsep teodisi yang utuh dan proporsional. Secara masif, para teolog dan pemikir Kristen menerbitkan beberapa buku terutama untuk menjawab problematika teologis seputar kuasa Allah dalam realitas

Certain Kind: Intentional Disciplemaking that Redefines Success in Ministry (Singapore: Covenant Evangelical Free Church, 2013), 65-81. 
pandemi, sebut saja Coronavirus and Christ dari pendeta John Piper, ${ }^{8}$ Where is God in a Coronavirus World? dari apologis dan ilmuwan John C. Lennox, ${ }^{9}$ dan God and the Pandemic dari teolog biblika N. T. Wright. ${ }^{10}$ Buku-buku ini, meskipun ditulis dalam disiplin ilmu dan pendekatan yang berlainan, tetapi seperti ingin menyuarakan pesan yang seragam: bahwa Allah berdaulat dan tetap mengasihi manusia sekali pun di tengah wabah yang tidak terpahami. Agaknya penerbitan judul-judul ini merupakan sebuah indikasi tentang langgengnya perdebatan tentang topik teodisi. Para pemimpin gereja perlu memperhatikan hal ini dan jika memungkinkan, memasukkan pesan tentang teodisi yang utuh dan tepat di dalam khotbah, pengajaran, persekutuan, bahkan pendampingan pastoral.

Menariknya, kebutuhan tentang teodisi yang tepat ini juga bukan hanya dapat dilihat dari penerbitan judul-judul di atas, tetapi juga berdasarkan pengamatan empiris khususnya dalam konteks Indonesia. Dalam paparan yang diberikannya pada Rembuknas STT SAAT (Mei 2020), Daniel Ronda, ketua sinode Gereja Kemah Injil Indonesia, menunjukkan bahwa ada "krisis teologis" yang dihadapi oleh masyarakat Kristen pedesaan. Krisis teologis tersebut antara lain: pemahaman bahwa pandemi ini terjadi sebagai hukuman Tuhan atas dosa manusia, pandemi ini merupakan tanda-tanda akhir zaman dan

\footnotetext{
${ }^{8}$ John Piper, Coronavirus and Christ (Wheaton: Crossway, 2020), Adobe PDF eBook, diakses tanggal 15 November 2020, https://document.desiringgod.org/corona virus-and-christ-en.pdf?ts $=1586278809$. Buku ini telah diterjemahkan ke dalam bahasa Indonesia oleh Philip Manurung dan diterbitkan dengan judul yang sama oleh Literatur Perkantas Jawa Timur, yang dapat diakses di http://corona.literaturperkantas.com.

${ }^{9}$ John C. Lennox, Where is God in a Coronavirus World? (The Good Book Company, 2020), Adobe PDF eBook. Buku ini sudah diterjemahkan ke dalam bahasa Indonesia oleh Budianto Lim dan diterbitkan oleh Literatur Perkantas Jawa Timur serta dapat diakses di: http://dimana. literaturperkantas.com. Ulasan tentang buku ini lih. Sandra Wisantoso, "Ulasan Buku: Where is God in a Coronavirus World," Veritas: Jurnal Teologi dan Pelayanan 19, no. 2 (2020): 113-116, diakses 15 November 2020, https://doi.org/ 10.36421/veritas.v19i1.365.
}

mendekatnya kedatangan Kristus kedua kali, serta adanya keengganan untuk memindahkan ibadah dari gereja ke rumah dengan alasan umat harus lebih takut akan Allah daripada takut tertular virus. ${ }^{11}$ Ronda menganalisis bahwa problematika teologis ini terjadi akibat kemunculan ajaran-ajaran yang keliru khususnya tentang teodisi tetapi marak tersebar di media massa dan media sosial. ${ }^{12}$

Kedua, masa pandemi menunjukkan bahwa pelayanan gereja masih sangat terfokus dan bergantung pada peran rohaniwan sebagai tenaga profesional dan belum melibatkan seluruh anggota tubuh Kristus sebagai komunitas pelayan. Pada masa pandemi, terlihat banyak sekali rohaniwan mencoba untuk membuat konten daring berupa khotbah, seminar, sapaan gembala, lagu pujian, dan berbagai bentuk lain. Akan tetapi, penelitian dari BRC justru menunjukkan bahwa jemaat justru merasa tidak mengalami engagement dari pendeta atau gembala jemaat setempat. Hal ini disebabkan misalnya oleh perubahan intensitas pelayanan dari tatap muka menjadi pembatasan fisik, adanya gembala atau pendeta yang tidak mengetahui kondisi spiritualitas atau pertumbuhan iman jemaatnya, serta jemaat menganggap bahwa pemberian renungan pastoral (secara digital) yang umum dilakukan oleh

${ }^{10}$ N. T. Wright, God and the Pandemic: A Christian Reflection on the Coronavirus and Its Aftermath (Grand Rapids: Zondervan, 2020). Sebelumnya, N. T. Wright sempat menuliskan sebuah artikel di majalah Time yang menuai banyak respons karena mengatakan bahwa orang Kristen seharusnya tidak perlu terlalu memberikan banyak respons terkait situasi pandemi COVID-19, melainkan harus belajar meratap di dalam situasi yang pedih ini (lih. N. T Wright, "Christianity Offers No Answers About the Coronavirus. It's Not Supposed To," Time, 29 Maret 2020, diakses 15 November 2020, https://time.com/5808495/ coronavirus-christianity).

${ }^{11}$ Daniel Ronda, "Tantangan Gereja-gereja di Daerah dan Pedalaman," disampaikan pada Rembuk Nasional STT SAAT, Mei 2020. Konteks "pedalaman" yang dimaksud di sini adalah kota kabupaten, kecamatan/distrik, desa dan kampung; mayoritas di wilayah Kalimantan, Nusa Tenggara Timur dan Papua.

${ }^{12}$ Ibid. 
para rohaniwan tidak serta-merta berarti sapaan personal kepadanya. ${ }^{13}$

Tanda-tanda ini sejatinya dapat dibaca dari dua sisi. Di satu sisi, tentu saja tanda-tanda ini memperslihatkan kreativitas dan inovasi para rohaniwan yang tetap setia melayani dan berkarya di tengah krisis. Akan tetapi, di sisi lain, tanda-tanda ini juga menunjukkan kecenderungan jemaat untuk "bergantung" dan terpusat pada pelayanan rohaniwan semata-mata, dan secara bersamaan menganggap diri mereka sebagai "konsumen" yang harus terus-menerus "disuapi" dan seolaholah "tidak bisa hidup" tanpa pelayanan rohaniwan. Padahal, sejatinya pertumbuhan rohani dan pelayanan kepada Allah merupakan tanggung jawab seluruh anggota tubuh Kristus, bukan hanya rohaniwan (bdk. Ef. 4:11-16).

\section{Catatan Ronda dalam Rembuknas STT SAAT} juga menegaskan hal ini. Ia mengatakan, dalam konteks pedesaan yang tidak semuanya memiliki tenaga rohaniwan yang cukup, sangat diperlukan pemberdayaan pelayan awam khususnya dalam berkhotbah dan memuridkan. ${ }^{14}$ Sebagai kesimpulan, Michael Teng dalam Rembuknas STT SAAT mendorong gerejagereja untuk membuka ruang sebesar-besarnya bagi keterlibatan pelayan awam dengan cara peralihan dari pelayanan yang berpusat pada rohaniwan menjadi berpusat pada rohaniwan dan pemimpin awam; peralihan dari pelayanan rohaniwan sebagai pelaksana tunggal menjadi sebagai pemerlengkap jemaat Allah; dan peralihan dari peran rohaniwan sebagai gembala bagi seluruh umat menjadi gembala bagi para anggota tim penggembala. ${ }^{15}$

Ketiga, masa pandemi menunjukkan bahwa pelayanan gereja masih secara sempit terfokus

\footnotetext{
${ }^{13}$ Ibid.

${ }^{14}$ Ronda, "Tantangan Gereja-gereja di Pedalaman," Rembuknas STT SAAT, Mei 2020.

${ }^{15}$ Michael Teng, Sylvia Soeherman, Junianawaty Suhendra, Damon Hakim, "Hasil Survenas 2020: Pelayanan Gereja di Masa Pandemi 19-28 April 2020," disampaikan pada Rembuk Nasional STT SAAT, 10 Mei 2020.

${ }^{16}$ Suriawan Edhi, "Respons Gereja Terhadap Pengalaman Ibadah Jemaat dalam Ibadah Online," dalam
}

hanya pada dimensi ibadah dan belum atau tidak holistik menyentuh bidang-bidang lain yang juga penting. Hal ini terlihat dari fokus gereja di paruh awal masa pandemi yang agaknya terkuras sepenuhnya pada penyelenggaraan dan penyediaan konten ibadah online di gereja masing-masing, baik secara tayangan langsung (live streaming) maupun tayangan yang sudah direkam sebelumnya (pre-recorded streaming). Gereja-gereja tampaknya berupaya sekuat tenaga untuk "bersaing" menghadirkan konten ibadah daring yang lebih baik. Hal ini sedikit banyak disebabkan oleh kekhawatiran bahwa jemaatnya akan lebih memilih mengikuti ibadah daring di gereja lain. Survei kuantitatif yang dilakukan oleh Sinode GKI Wilayah Jawa Barat menunjukkan bahwa $80 \%$ jemaat mengikuti ibadah dan pelayanan daring di gerejanya, namun di saat bersamaan $60 \%$ jemaat mengikuti ibadah daring di kanal atau situs gereja lain. ${ }^{16}$

Upaya untuk "memenangkan" persaingan viewers di tengah dunia ibadah digital ini juga ditangkap dalam data Survei Nasional STT SAAT Mei 2020 yang dipresentasikan oleh Teng dalam Rembuknas STT SAAT. Teng menyimpulkan bahwa di awal masa pandemi perhatian utama gereja-gereja ada pada pelaksanaan ibadah, sementara hal-hal lainnya dilakukan dengan agak gagap dan tidak terpikirkan. Fenomena ini, menurut Teng, terjadi karena sejak sebelum pandemi pun fokus perhatian gereja-gereja memang lebih banyak tertuju pada ibadah Minggu, dan kurang pada aspek-aspek penting lainnya dalam pelayanan gerejawi. ${ }^{17}$ Tambahan pula, berdasarkan pembacaan Yohanes Adrie Hartopo terhadap penelitian pengalaman ibadah jemaat dalam beribadah daring khususnya dalam konteks gereja di perkotaan, upaya pembuatan konten

Webinar Hasil Survei Pengalaman Ibadah Jemaat dalam Ibadah Online, Pusat Studi Pertumbuhan Gereja (PSPG) STT Amanat Agung, Jakarta, 8 Juni 2020. Kekhawatiran yang dimaksud adalah jika di masa pandemi jemaat sangat mudah membanding-bandingkan layanan ibadah daring gerejanya dengan gereja lain, maka dikhawatirkan setelah masa pandemi jemaat akan benar-benar berpindah hati, fisik, dan bahkan keanggotaan.

${ }^{17}$ Teng, dkk, "Hasil Survenas 2020." 
ibadah daring adalah hal yang tidak mudah, bahkan dapat dikatakan sangat menguras energi, waktu, tenaga, dan sumber daya baik manusia maupun material. ${ }^{18}$

Tentu saja pelayanan ibadah bukan tidak penting, tetapi realita di masa sebelum dan selama pandemi menunjukkan adanya perhatian yang tidak seimbang: terlalu berfokus kepada ibadah dan mengabaikan bidangbidang lain yang sama pentingnya. Penelitian dari BRC menunjukkan setidaknya empat elemen pelayanan selain ibadah yang "terabaikan" atau kurang mendapat perhatian yang cukup, yaitu: keuangan, sekolah Minggu, pelayanan keluarga, dan penginjilan. ${ }^{19} \mathrm{Hal}$ ini patut dipikirkan secara serius karena gereja yang sehat tidak hanya perlu memikirkan aspek ibadah, tetapi juga aspek-aspek lain seperti persekutuan, pengajaran, dan kesaksian. $^{20}$ Di samping itu, ada pula beragam pelayanan yang berbasis kebutuhan (needsbased ministry) seperti misalnya pelayanan kelompok usia tertentu dalam kelompok kecil, pelayanan konseling, pelayanan di ruang sosial, dan pelayanan pemberdayaan ekonomi jemaat yang juga patut mendapat perhatian gereja. $^{21}$

Keempat, masa pandemi menunjukkan adanya kesenjangan ( $g$ ap ) yang serius antara generasi tua dan muda di dalam gereja. Kesenjangan antara generasi tua (senior) dan muda (junior) ini terjadi bukan hanya di kalangan jemaat awam, tetapi mula-mula dari kalangan rohaniwan. Lagi-lagi penelitian dari BRC memperlihatkan temuan yang menarik. Dilansir bahwa kebanyakan ibadah utama yang ditayangkan secara online dilayani oleh hambahamba Tuhan yang senior, sehingga hamba-

\footnotetext{
${ }^{18}$ Yohanes A. Hartopo, "Tantangan yang Dihadap Gereja-gereja Perkotaan di Masa Pandemi dan Pasca Pandemi," disampaikan dalam Rembuknas STT SAAT, 10 Mei 2020; bdk. "Webinar Hasil Survei Pengalaman Ibadah Jemaat dalam Ibadah Online," PSPG STT Amanat Agung, Jakarta, 8 Juni 2020.

${ }^{19}$ Irawan dan Putra, "7 Tantangan Gereja," Bilangan Research Center, 2020.

${ }^{20}$ John Stott, The Living Church: Convictions of a Lifelong Pastor (Downers Grove: InterVarsity, 2011).
}

hamba Tuhan muda atau yang masih junior merasa tidak dibutuhkan dan tidak mendapat kesempatan. $^{22}$

Terlepas dari faktor-faktor internal gereja masing-masing, realita ini menunjukkan ada masalah dalam regenerasi kepemimpinan dan pelayanan gereja. Padahal, dalam disertasinya yang meneliti tentang revitalisasi gereja pada empat gereja lokal dari empat sinode berbeda di empat kota besar di Indonesia, Teng menunjukkan salah satu faktor penyebab revitalisasi gereja adalah adanya tim kepemimpinan bersifat intergenerasi yang kuat dan harmonis. ${ }^{23}$ Penemuan ini juga diteguhkan kembali dalam Rembuknas STT SAAT. Dalam panel diskusi Rembuknas STT SAAT tentang pelayanan kaum muda, didapati bahwa kaum muda di gereja-gereja (injili) menghadapi kesulitan dalam mengikuti ibadah, salah satunya karena "konsumsi" dalam ibadah umum dirasa terlalu berat. ${ }^{24} \mathrm{Hal}$ ini menunjukkan belum ada, atau kurangnya, pemahaman dan praktik pelayanan-pelayanan bersifat intergenerasi di dalam gereja.

Kelima, masa pandemi menunjukkan bahwa gereja-gereja pada umumnya tidak siap berhadapan dengan kemajuan teknologi. Temuan ini dilaporkan oleh BRC dan Yakub Tri Handoko dalam catatan keynote speaker mengenai konteks gereja berbasis pelayanan digital. Hasil penelitian BRC menunjukkan bahwa tidak semua gereja bisa mengadakan ibadah online, karena ada yang tidak mempunyai infrastruktur yang memadai, atau ada pula yang tidak mengetahui caranya padahal infrastruktur yang dimiliki cukup mendukung. ${ }^{25}$ Selain itu, dalam penelitian lain yang dilakukan BRC secara kuantitatif terhadap

\footnotetext{
${ }^{21}$ Teng, dkk, "Hasil Survenas 2020."

${ }^{22}$ Irawan dan Putra, "7 Tantangan Gereja," Bilangan Research Center, 2020.

${ }^{23}$ Michael Teng, "Factors That Contribute to Turnaround Churches in the Indonesian Context" (Disertasi, Biola University, 2018).

${ }^{24}$ Michelle A. Kartono, ed., "Cluster Keluarga: Project Groups Pelayanan Anak, Kaum Muda, dan Keluarga," disampaikan dalam Rembuknas STT SAAT, 18 Mei 2020.

${ }^{25}$ Ibid.
} 
berbagai gereja di perkotaan Indonesia dari tiga aliran berbeda (mainstream, injili dan Pentakosta/Karismatik), didapati bahwa sebagian besar gereja tidak mempunyai bidang atau komisi khusus digital, dan kalau pun ada, pada umumnya baru dibentuk pada masa pandemi COVID-19. ${ }^{26}$ Handoko dalam Rembuknas STT SAAT meringkaskan fenomena ini dengan dua poin, yaitu bahwa banyak gereja masih enggan dan tergopoh-gopoh mengikuti perkembangan teknologi; serta banyak hamba Tuhan dan gereja injili yang belum serius menggarap pelayanan digital. ${ }^{27}$

Beberapa temuan di atas menunjukkan bahwa masa pandemi menjadi cermin yang merefleksikan wajah gereja sesungguhnya. Tentu saja poin-poin ini hanya dipaparkan secara garis besar dan umum. Masih ada poin-poin spesifik lain yang tidak terangkum. Tetapi, dari kelima poin di atas, agaknya tidak berlebihan untuk menyimpulkan bahwa observasi yang telah dimiliki tentang pelayanan gereja selama ini dapat terbukti benar. Adanya ambiguitas visi teologis dalam pelayanan yang berakibat juga pada ambiguitas praksis pelayanan. Pertanyaan selanjutnya yang perlu digumulkan adalah: bagaimana kemudian gereja merevitalisasi pelayanannya di dalam masa kenormalan baru bahkan sesudah masa pandemi?

\section{PELAYANAN GEREJA SESUDAH MASA PANDEMI: SEBUAH ANTISIPASI}

Mengasumsikan bahwa pelayanan gereja akan serta-merta berubah setelah diterpa pandemi adalah sebuah kekeliruan yang sama dengan harapan kosong. Seorang pengajar dan peneliti pertumbuhan gereja bernama Ed Stetzer berkata bahwa di tengah anggapan banyak orang tentang perubahan pelayanan gereja

\footnotetext{
${ }^{26}$ Bilangan Research Center, "Pelayanan dan Dinamika Gereja Selama Masa Pandemi COVID-19," disampaikan pada Zoominar Hasil Temuan Survei Nasional, Bilangan Research Center, 2020.

${ }^{27}$ Yakub Tri Handoko, "Gereja Berbasis Anak Muda," Rembuk Nasional STT SAAT, 10 Mei 2020.

${ }^{28}$ Ed Stetzer, "Time for a New Normal," Christianity Today, 9 Juli 2020, diakses 20 Desember 2020, https://www.
}

secara besar-besaran setelah pukulan pandemi, ia justru lebih mengkhawatirkan pelayanan gereja yang akan kembali menjadi sama lagi seperti sebelum pandemi dan tidak akan mengalami perubahan apa-apa. ${ }^{28}$ Menurutnya, gereja sepanjang zaman telah mengalami berbagai gejolak tantangan dan "pandemi" lain selain COVID-19, tetapi tetap tidak mudah untuk meninggalkan perspektif yang keliru dan cara pelayanan yang kurang efektif. $^{29}$ Jika demikian, maka apa lagi yang dapat kita katakan? Atau lebih tepatnya, jika pandemi yang berpengaruh sebesar ini saja tidak cukup untuk membawa pembaharuan, maka apa atau siapa yang mampu melakukannya? Lalu, bagaimana cara mewujudkan pembaharuan tersebut?

Tentu saja peringatan Stetzer ini tidak bertujuan untuk mematahkan semangat pelayanan gereja atau membuyarkan semangat di masa datang, melainkan justru menjadi sebuah catatan serius yang perlu diperhatikan. Setelah menyadari beberapa hasil observasi dan melihat pantulan realita dari "cermin" pandemi, sudah waktunya gereja-gereja memikirkan hal-hal yang seharusnya ada dan diupayakan tetapi mungkin selama ini diabaikan. Thom Rainer di dalam bukunya The Post-Quarantine Church mengatakan bahwa masa pascapandemi merupakan waktu yang ideal untuk gereja menata ulang (reset) pelayanannya menjadi lebih selaras dengan Injil. ${ }^{30}$

Akan tetapi, perlu terlebih dahulu dicatat bahwa dunia pelayanan gerejawi pascapandemi itu sendiri adalah sesuatu yang masih buram, tidak pasti, dan belum terpetakan (uncharted), bahkan secara waktu sekali pun belum ada yang dapat memastikan kapan masa pandemi ini akan benar-benar berakhir.

christianitytoday.com/edstetzer/2020/july/time-for-newnormal.html.

${ }^{29}$ Ibid.

${ }^{30}$ Thom S. Rainer, The Post-Quarantine Church: Six Urgent Challenges and Opportunities That Will Determine the Future of Your Congregation (Carol Stream: Tyndale Momentum, 2020), Introduction, Kindle. 
Maka, alih-alih menjadi panduan atau "tips dan trik" pelayanan, bagian ini ditulis lebih sebagai sebuah antisipasi. Melalui observasi sebelum masa pandemi dan pantulan wajah gereja dari berbagai temuan penelitian di masa pandemi, setidaknya dapat dianalisis hal-hal yang perlu dikaji ulang dalam pelayanan gereja.

Hal esensial yang perlu diingat dan dikaji ulang bagi pelayanan pascapandemi adalah tujuan eksistensi gereja, yaitu melakukan pelayanan kepada Allah melalui ibadah, pelayanan kepada sesama melalui pembinaan dan penggembalaan, serta pelayanan kepada dunia melalui pekabaran Injil dan kesaksian sosial. ${ }^{31}$ Ketiga dimensi pelayanan ini perlu dijalankan dengan utuh dan seimbang. Untuk itu, penulis berpandangan bahwa gereja perlu menata ulang fokus perhatian (refocus) kepada setidaknya enam hal untuk mencapai tujuan ini.

Pertama, gereja perlu berfokus untuk mempersempit atau bahkan menghilangkan kesenjangan antara teologi dan praksis pelayanan, dengan cara membangun sebuah visi atau refleksi teologis yang sehat dan menjadi nilai utama yang terpenetrasi dan mempengaruhi seluruh dinamika pelayanan. Tim Keller menjelaskan hal ini dengan menarik. Ia memaparkan bahwa gereja pada umumnya memiliki "perangkat lunak" kebenaran doktrinal, pengakuan iman, falsafah teologis, atau eksposisi biblikal. Gereja juga pada umumnya memiliki "perangkat keras" praktik pelayanan, struktur organisasi, tata gereja, atau sistem pengelolaan pelayanan. Tetapi, kedua hal ini saja tidak cukup dan justru malah sering dipertentangkan satu sama lain. Gereja membutuhkan "perangkat tengah" (middleware) refleksi teologis, yaitu bagaimana konsep teologis yang

\footnotetext{
${ }^{31}$ Keller, Center Church, 300-332; bdk. Michael Teng "Mempersiapkan Gereja Pasca Pandemi." Tidak diterbitkan.

${ }^{32}$ Keller, Center Church, 14-15.

${ }^{33}$ Literatur lain yang secara ekstensif membahas tentang refleksi teologis dalam dunia kejemaatan dan pelayanan, lih. Kevin J. Vanhoozer \& Owen J. Stratchan, The Pastor as Public Theologians: Reclaiming a Lost Vision (Grand
}

solid diejawantahkan dan dihidupi dalam konteks yang spesifik. ${ }^{32}$ Agaknya, refleksi teologis ini yang akan sangat menentukan respons gereja ketika menghadapi berbagai perubahan zaman dan tantangan eksternal seperti pandemi. Refleksi teologis inilah yang akan membuat kebenaran Alkitab tidak hanya menjadi milik para tokoh Alkitab atau teolog, tetapi menjadi milik seluruh jemaat Kristus.

Namun, apa dan bagaimana sebenarnya bentuk konkret dari refleksi teologis ini? Ed Stetzer menjelaskan bahwa refleksi teologis ini merupakan hal berharga yang harus dimiliki dan dihasilkan oleh pemimpin gereja. Ia menyebutnya dengan istilah "praktikalitas." Praktikalitas ini berbeda dengan pragmatisme atau semangat hanya mau mengurusi hal-hal operasional tanpa memikirkan hal-hal yang filosofis, teologis dan fondasional. Praktikalitas ini adalah kemampuan pemimpin dan jemaat gereja untuk mencerna teologi secara dalam dan matang, kemudian mengartikulasikannya dalam praktik hidup keseharian dan pelayanan, untuk memobilisasi umat Tuhan melaksanakan Amanat Agung di tengah dunia. Praktikalitas ini dapat dibangun dengan misalnya memasukkan aspek refleksi teologis, ilustrasi, atau aplikasi yang konkret di dalam khotbah dan pengajaran, serta melatih jemaat untuk bertanya: "Apa artinya bagi saya?" untuk setiap kebenaran teologi yang dicerna dan didapatkan. ${ }^{33}$ Kedua, gereja perlu fokus kepada ibadah sebagai sentral (central) dalam pelayanan, tetapi bukan pusat (center) dari bagian-bagian pelayanan yang lain. ${ }^{34}$ Pelayanan ibadah seharusnya tidak dianggap lebih superior dan semua bidang pelayanan lain hanya "pelengkap" untuk ibadah. Melainkan, pelayanan ibadah seharusnya menjadi sentral yang menjadi pusat pertemuan sekaligus

Rapids: Baker Academic, 2015); Kevin J. Vanhoozer, Hearers \& Doers: A Pastor's Guide to Making Disciples Through Scripture and Doctrine (Bellingham: Lexham, 2019); Keith L. Johnson, Theology as Discipleship (London: InterVarsity, 2016).

${ }^{34}$ Stetzer, "Time for a New Normal," bdk. Keller, Center Church, 300-312. 
memberi daya bagi sendi-sendi kehidupan gerejawi lainnya. Melalui pelayanan ibadah yang dipersiapkan dengan baik, meliputi liturgi yang menceritakan Injil Kristus, khotbah yang berakar pada pengajaran Kitab Suci yang kokoh dan lurus, serta sakramen yang dilaksanakan dengan setia, jemaat dapat dipikat dalam narasi misi Kristus di dalam dunia dan justru digerakkan untuk menghidupi dan mewartakan Injil. ${ }^{35}$ Ibadah yang dipersiapkan dengan baik juga dapat menjadi kesaksian bagi orang-orang di luar kekristenan tentang narasi Injil yang menyelamatkan. Adalah penting untuk mempersiapkan ibadah dengan baik, tetapi perlu dicatat juga bahwa pelayanan ibadah bukanlah satu-satunya apalagi segalagalanya di dalam dinamika bergereja.

Perlu disadari bahwa pelayanan ibadah pascapandemi mungkin akan berbeda dengan keadaan sebelum pandemi. Setelah adanya budaya pelayanan daring, gereja perlu memikirkan dengan strategis mengenai pertemuanpertemuan yang dilakukan dan secara fisik, dan pelayanan serta penjangkauan yang dapat atau perlu juga dilakukan secara digital. ${ }^{36}$ Konsekuensinya, alokasi dana untuk pengadaan dan pemeliharaan fasilitas fisik dapat dialihkan guna menunjang bentuk-bentuk pelayanan lain. Pun pelayanan ibadah dapat secara bersamaan dikelola sebagai sarana penjangkauan dan pemberitaan Injil dalam dunia global.

Ketiga, gereja perlu berfokus pada pembinaan dan pemuridan berbasis keluarga. Masa pandemi telah menunjukkan bahwa pelayanan mimbar yang terpusat hanya dari dan di dalam gereja, serta dilakukan semata-mata oleh rohaniwan sebagai tenaga profesional, adalah

${ }^{35}$ Michael Goheen, $A$ Light to the Nations: The Missional Church and the Biblical Story (Grand Rapids: Baker Academic, 2011), 202-208; David E. Fitch, Faithful Presence: Seven Disciplines That Shape the Church for Mission (Grand Rapids: Baker Academic, 2016), bab 1, Kindle.

${ }^{36}$ Rainer, The Post-Quarantine Church, bab 1, bab 5, Kindle.

${ }^{37}$ Lih. mis. Reggie Joiner, Think Orange: Imagine the Impact When Church and Family Collide (Colorado: David tidak cukup dan sangat terbatas dalam menjawab kebutuhan rohani jemaat. Di tengah realita jemaat yang "dipulangkan ke rumah" dan segala sesuatunya berlangsung dari rumah, maka pelayanan keluarga menjadi sangat sentral dan penting. Urgensi pelayanan keluarga ini menjadi tambah meningkat dalam konteks pelayanan yang mungkin minim tenaga rohaniwan profesional. Karena itu, gereja perlu menyadari dan mengedepankan pentingnya pelayanan pembinaan iman dan pemuridan yang dimulai dan berbasis dari keluarga. Dalam bentuk ini, keluarga dipandang sebagai pemurid yang utama dan gereja memainkan peran untuk memperlengkapi orang tua membina iman anak-anak. ${ }^{37}$ Gereja dapat menjalankan pelayanan ini misalnya dengan memperlengkapi dan melatih orang tua dalam materi dan keterampilan mengadakan ibadah keluarga, mengajar sekolah Minggu anak-anak di rumah, dan mengadakan percakapan iman (faith talk), serta menyediakan mentor-mentor yang dapat mendampingi orang tua dalam proses bertumbuh membina iman anak dari rumah.

Keempat, gereja perlu berfokus pada pelayanan pastoral yang menekankan relasi personal yang mendalam. Sudah banyak saran-saran pelayanan dan konsep penggembalaan yang mengemukakan pentingnya orang (people) daripada program. ${ }^{38}$ Tetapi, sesering itu pula "relasi dengan orang" yang digemakan itu justru kembali berakhir dan terhenti menjadi sebuah program lain. Ada banyak faktor yang bisa menyebabkan hal ini, tetapi harus diakui bahwa menjalin relasi yang otentik dan mendalam merupakan perkara yang tidak mudah dan bahkan bisa menuntut harga yang "lebih mahal" dibandingkan dengan menjalankan

C. Cook, 2009); Kara Powell dan Steven Argue, Growing With: Every Parent's Guide to Helping Teenagers and Young Adults Thrive in Their Faith, Family, and Future (Grand Rapids: Baker, 2019); Kara Powell dan Chap Clark, Sticky Faith: Everyday Ideas to Build Lasting Faith in Your Kids (Grand Rapids: Zondervan, 2011).

${ }^{38}$ Lih. mis. Marshall dan Payne, The Trellis and the Vine, 8-11. 
agenda kegiatan semata. ${ }^{39}$ Tentu saja keterbatasan kapasitas seorang rohaniwan tidak akan cukup untuk menopang kebutuhan relasional ini. Karena itu, gereja perlu beralih dari pelayanan yang berpusat pada rohaniwan (pastor-centered) menjadi kombinasi dan sinergi antara pelayanan rohaniwan dan para pemimpin awam. Tenaga rohaniwan tidak lagi berfungsi sebagai "pemain tunggal" (sole doer) dan satu gembala bagi seluruh gereja, melainkan berubah menjadi pemerlengkap (equipper) tubuh Kristus dan gembala bagi para gembala lain. Hanya dengan sinergi, kolaborasi, dan pemberdayaan kaum awam seperti ini, relasi yang mendalam antara seluruh anggota tubuh Kristus dapat tercipta.

Kelima, gereja perlu fokus kepada pengembangan pelayanan dan penjangkauan generasi muda. Pelibatan dan penjangkauan kaum muda ini menjadi penting khususnya di era setelah pandemi, ketika pelayanan digital akan menjadi sebuah keniscayaan. Fokus melibatkan dan menjangkau generasi muda ini dapat dimulai dengan misalnya memberi ruang bagi hamba-hamba Tuhan muda (junior) untuk mengambil peran strategis dalam pelayanan, sementara hamba Tuhan senior dapat berperan sebagai mentor, pelatih, atau penasihat yang mendukung. Selain itu, gereja juga perlu membuka pintu lebih lebar bagi generasi muda untuk berada pada posisi konseptor, pengambil keputusan, atau bagian dari tim kepemimpinan, dan bukan hanya "pelaku" atau "asisten" dari orang-orang dewasa. ${ }^{40}$

Sebagai catatan, pelibatan generasi muda dan pemuridan berbasis keluarga sebenarnya dapat dijalankan bersamaan melalui model pelayanan intergenerasi. Pelayanan intergenerasi

\footnotetext{
${ }^{39}$ Timothy Lane dan Paul David Tripp, Relationships: $A$ Mess Worth Making (Greensboro: New Growth, 2008); bdk. Marshall dan Payne, The Trellis and the Vine, 9.

${ }^{40}$ Handoko, "Gereja Berbasis Anak Muda," Rembuknas STT SAAT, 2020; bdk. Kara Powell, Jake Mulder, dan Brad Griffin, Growing Young: Six Essential Strategies to Help Young People Discover and Love Your Church (Grand Rapids: Baker, 2016), 50-87.

${ }^{41}$ Holly Catterton Allen dan Christine Lawton Ross, Intergenerational Christian Formation: Bringing the Whole
}

terjadi ketika sebuah gereja secara intensional membawa dan memfasilitasi berbagai generasi yang berbeda untuk terlibat di dalam proses saling beribadah, berkomunitas, dan melayani bersama-sama sebagai bagian dari satu kesatuan tubuh Kristus. ${ }^{41}$ Pelayanan intergenerasi dibangun atas keyakinan bahwa seluruh anggota jemaat, dalam kelompok usia mana pun, adalah bagian yang sama penting dan setara dalam kesatuan tubuh Kristus, dan pertumbuhan dapat terjadi dengan lebih ideal jika diupayakan ketersalingan. ${ }^{42}$ Pelayanan intergenerasi memberi ruang bagi pemberdayaan generasi muda sekaligus memperlengkapi orang tua untuk menjadi pembina iman dan teladan rohani.

Terakhir, gereja perlu berfokus pada kapasitas pengutusan (sending capacity) ketimbang kapasitas penampungan jemaat (seating capacity). ${ }^{43}$ Pandemi membukakan gereja bahwa Kerajaan Allah memiliki cakupan global dan bukan hanya berdimensi lokal dalam satu gereja atau sinode tertentu. Maka, sudah sepatutnya gereja mengubah tolok ukur keberhasilannya dari kehadiran (attendance), bangunan fisik (building), dan keuangan (cash) menjadi kapasitas pengutusan (sending) jemaat sebagai pelayan Allah di tengah dunia. Gereja perlu mengingat bahwa umat Allah seharusnya diutus ke tengah dunia, bukan hanya di dalam tembok gereja. Gereja perlu memperlengkapi jemaat untuk menjadi utusan "misi" Allah di dalam pekerjaan, keluarga, lingkungan, bahkan dunia digital.

Church Together in Ministry, Community and Worship (Downers Grove: InterVarsity, 2012), 17.

${ }^{42}$ Powell dan Argue, Growing With, 23; bdk. David Kinnaman dan Mark Matlock, Faith for Exiles: 5 Ways for a New Generation to Follow Jesus in Digital Babylon (Grand Rapids: Baker, 2019), 113.

${ }^{43}$ J.D. Greear, Gaining by Losing: Why the Future Belongs to Churches that Send (Grand Rapids: Zondervan, 2015) 16, 19, 21, 29. 


\section{KESIMPULAN: GEREJA YANG TENGGELAM, BERTAHAN, ATAU BERKEMBANG?}

Masa pandemi telah menjadi sebuah gelombang besar yang mengejutkan pelayanan gereja. Sampai sekarang, masih belum jelas kapan pandemi ini akan berakhir dan apa (saja) sisa-sisa dampak yang ditinggalkannya. Tetapi, gereja Tuhan mempunyai pilihan: akan "tenggelam" dan mati (dying), bertahan (surviving) atau justru maju pesat dan berkembang (thriving). Anugerah Allah yang akan memampukan gereja tetap bertahan dan bahkan berkembang di tengah realitas pandemi, tetapi juga diperlukan antisipasi dan langkahlangkah hikmat yang diambil dan diterapkan. Kiranya cerminan wajah gereja yang telah ditunjukkan selama masa pandemi ini tidak kembali diabaikan, tetapi justru dapat dijadikan bahan refleksi dan evaluasi untuk menaati kehendak Tuhan dengan lebih efektif dan jernih.

\section{DAFTAR KEPUSTAKAAN}

Allen, Holly Catterton dan Christine Lawton Ross. Intergenerational Christian Formation: Bringing the Whole Church Together in Ministry, Community and Worship. Downers Grove: InterVarsity, 2012.

Bilangan Research Center. "Pelayanan dan Dinamika Gereja Selama Masa Pandemi COVID-19." Disampaikan pada Zoominar Hasil Temuan Survei Nasional Bilangan Research Center, 2020.

Chan, Edmund. A Certain Kind: Intentional Disciplemaking that Redefines Success in Ministry. Singapore: Covenant Evangelical Free Church, 2013.

Edhi, Suriawan. "Respons Gereja Terhadap Pengalaman Ibadah Jemaat dalam Ibadah Online." Disampaikan dalam Webinar Hasil Survei Pengalaman Ibadah Jemaat dalam Ibadah Online. Pusat Studi Pertumbuhan Gereja (PSPG) STT Amanat Agung. Jakarta, 8 Juni 2020.
Fitch, David E. Faithful Presence: Seven Disciplines That Shape the Church for Mission. Grand Rapids: Baker Academic, 2016.

Goheen, Michael. A Light to the Nations: The Missional Church and the Biblical Story. Grand Rapids: Baker Academic, 2011.

Greear, J.D. Gaining by Losing: Why the Future Belongs to Churches that Send. Grand Rapids: Zondervan, 2015.

Hamilton, Craig. Wisdom in Leadership: The How and Why of Leading the People You Serve. Sydney: Matthias Media, 2015.

Handoko, Yakub Tri. "Gereja Berbasis Anak Muda." Disampaikan dalam Rembuk Nasional STT SAAT. Malang, 10 Mei 2020.

Hartopo, Yohanes Adrie. "Tantangan yang Dihadapi Gereja-gereja Perkotaan di Masa Pandemi dan Pascapandemi." Disampaikan dalam Rembuk Nasional STT SAAT. Malang, 10 Mei 2020.

_. "Webinar Hasil Survei Pengalaman Ibadah Jemaat dalam Ibadah Online." Pusat Studi Pertumbuhan Gereja (PSPG) STT Amanat Agung. Jakarta, 8 Juni 2020. Hutahean, Hasahatan, Bonnarty Steven Silalahi, Linda Zenita Simanjuntak. "Spiritualitas Pandemik: Tinjauan Fenomenologi Ibadah di Rumah.” Evangelikal: Jurnal Teologi Injili dan Pembinaan Warga Jemaat 4, no. 2 (Juli 2020): 234-249, https://doi.org/10.46445/ejti.v4i2.270

Irawan, Handi dan Cemara A. Putra. "7 Tantangan Gereja di Masa Pandemi COVID-19 dan Alternatif Solusinya." Bilangan Research Center, 2020. Tidak diterbitkan.

Johnson, Keith L. Theology as Discipleship. London: InterVarsity, 2016.

Joiner, Reggie. Think Orange: Imagine the Impact When Church and Family Collide. Colorado: David C. Cook, 2009.

Kartono, Michelle A., ed. "Cluster Keluarga: Project Groups Pelayanan Anak, Kaum Muda, dan Keluarga." Disampaikan dalam Rembuk Nasional STT SAAT. Malang, 18 Mei 2020. 
Keller, Timothy. Center Church: Doing Balanced, Gospel-Centered Ministry in Your City. Grand Rapids: Zondervan, 2012.

Kinnaman, David dan Mark Matlock. Faith for Exiles: 5 Ways for a New Generation to Follow Jesus in Digital Babylon. Grand Rapids: Baker, 2019.

Lane, Timothy dan Paul David Tripp. Relationships: A Mess Worth Making. Greensboro: New Growth, 2008.

Lennox, John C. Where is God in a Coronavirus World? The Good Book Company, 2020.

Marshall, Collin dan Tony Payne. The Trellis and the Vine: The Ministry Mind-shift that Changes Everything. Sydney: Matthias Media, 2009.

Partners in Ministry. "How Did a Range of Churches Meet the Challenge of Church on Sunday $22^{\text {nd }}$ March 2020?" Partners in Ministry. Maret 2020. Diakses 28 Agustus 2020. https://www.partnersinministry.com/ resources/churches-under-self-isolation.

Piper, John. Coronavirus and Christ. Wheaton: Crossway, 2020.

Powell, Kara dan Chap Clark. Sticky Faith: Everyday Ideas to Build Lasting Faith in Your Kids. Grand Rapids: Zondervan, 2011.

Powell, Kara dan Steven Argue. Growing With: Every Parent's Guide to Helping Teenagers and Young Adults Thrive in Their Faith, Family, and Future. Grand Rapids: Baker, 2019.

Powell, Kara, Jake Mulder dan Brad Griffin, Growing Young: Six Essential Strategies to Help Young People Discover and Love Your Church. Grand Rapids: Baker, 2016.

Rainer, Thom S. The Post-Quarantine Church: Six Urgent Challenges and Opportunities That Will Determine the Future of Your Congregation. Carol Stream: Tyndale Momentum, 2020.

Ronda, Daniel. "Tantangan Gereja-gereja di Daerah dan Pedalaman." Disampaikan pada Rembuk Nasional STT SAAT. Malang, 18 Mei 2020.

Stetzer, Ed. "Time for a New Normal," Christianity Today, 9 Juli 2020, diakses 20 Desember 2020. https://www.christianity today.com/edstetzer/2020/july/time-fornew-normal.html.

- "Why Being Fruitful is as Important as Being Faithful," Vision Room, diakses pada 27 Desember 2020. https://www.vision room.com/fruitful-important-faithful

Stott, John. The Living Church: Convictions of a Lifelong Pastor. Downers Grove: InterVarsity, 2011.

Teng, Michael, Sylvia Soeherman, Junianawaty Suhendra, Damon Hakim, "Hasil Survenas 2020: Pelayanan Gereja di Masa Pandemi 19-28 April 2020.” Disampaikan pada Rembuk Nasional STT SAAT. Malang, 10 Mei 2020.

- "Mempersiapkan Gereja Pascapandemi." Tidak Diterbitkan.

Teng, Michael. Factors That Contribute to Turnaround Churches in the Indonesian Context. Disertasi, Biola University, 2018.

Vanhoozer, Kevin J. Hearers \& Doers: A Pastor's Guide to Making Disciples Through Scripture and Doctrine. Bellingham: Lexham, 2019.

Vanhoozer, Kevin J dan Owen J. Stratchan. The Pastor as Public Theologians: Reclaiming a Lost Vision. Grand Rapids: Baker Academic, 2015.

Wright, N. T. "Christianity Offers No Answers About the Coronavirus. It's Not Supposed To.” Time, 29 Maret 2020, diakses 15 November 2020. https:/time.com/5808495/ coronavirus-christianity.

- God and the Pandemic: A Christian Reflection on the Coronavirus and Its Aftermath. Grand Rapids: Zondervan, 2020. 
